\title{
T4 Lysozyme and Attacin Genes Enhance Resistance of Transgenic 'Galaxy' Apple against Erwinia amylovora
}

\author{
Kisung Ko, ${ }^{1,3}$ John L. Norelli, ${ }^{2,4}$ Jean-Paul Reynoird, ${ }^{2}$ Herb S. Aldwinckle, ${ }^{2}$ and Susan K. Brown ${ }^{1}$ \\ Cornell University, New York State Agricultural Experiment Station, Geneva, NY 14456
}

\begin{abstract}
ADDITIONAL INDEX wORDS. apple transformation, quantitative western blot, Malus, microbicidal
Abstract. Genes encoding lysozyme (T4L) from T4 bacteriophage and attacin E (attE) from Hyalophora cecropia were used, either singly or in combination, to construct plant binary vectors, pLDB15, p35SAMVT4, and pPin2Att35SAMVT4, respectively, for Agrobacterium-mediated transformation of 'Galaxy' apple, to enhance resistance to Erwinia amylovora. In these plasmids, the $T 4 L$ gene was controlled by the cauliflower mosaic virus $35 \mathrm{~S}$ promoter with duplicated upstream domain and the untranslated leader sequence of alfalfa mosaic virus RNA 4, and the attE gene was controlled by the potato proteinase inhibitor II (Pin2) promoter. All transgenic lines were screened by polymerase chain reaction (PCR) for $T 4 L$ and $a t t E$ genes, and a double-antibody sandwich enzyme-linked immunosorbent assay for neomycin phosphotransferase II. Amplification of $T 4 \mathrm{~L}$ and $\mathrm{attE}$ genes was observed in reverse transcriptase-PCR, indicating that these genes were transcribed in all tested transgenic lines containing each gene. The attacin protein was detected in all att $\mathrm{E}$ transgenic lines. The expression of att $\mathrm{E}$ under the Pin2 promoter was constitutive but higher levels of expression were observed after mechanical wounding. Some $T 4 L$ or att $E$ transgenic lines had significant disease reduction compared to nontransgenic ' $G a l a x y$ '. However, transgenic lines containing both att $\mathrm{E}$ and $T 4 L$ genes were not significantly more resistant than nontransgenic ' $G a l a x y$ ', indicating that there was no in planta synergy between $a t t E$ and $T 4 L$ with respect to resistance to $E$. amylovora.
\end{abstract}

Fire blight, caused by Erwinia amylovora (Burr.) Winslow et al., is one of the most destructive diseases of apple (Malus sp.) and pear (Pyrus sp.), and many Rosaceous ornamental plants in many production regions (Sobiczewski et al., 1997). Many commercial apple scion cultivars including 'Gala', 'Idared', 'Jonathan', 'Fuji', and 'Gingergold' and the rootstocks, 'M.9' and 'M.26' are highly susceptible to E. amylovora (Aldwinckle et al., 1998). Introduction of antibacterial protein genes using Agrobacterium-mediated transformation could be an effective way to enhance resistance to phytopathogenic bacteria (Destéfano-Beltránet al., 1993; Montanelli and Nascari, 1990; Mourgues et al., 1998a; Norelli et al., 1994; Reynoird et al., 1999).

Attacin is an antimicrobial protein that is induced in Hyalophora cecropia (giant silk moth) pupae in response to bacterial infection. The gene encoding attacin $\mathrm{E}$ (attE) has been transferred to tobacco (Nicotiana tabacum var. Xanthi) (Destéfano-Beltrán, 1991), apple rootstocks and scion cultivars (Borejsza-Wysocka et al., 1999; Ko et al., 2000; Norelli et al., 1994), pear ( $P$. communis L.) (Reynoird et al., 1999) and anthurium (Anthurium andraeanum) (Chen and Keuhnle, 1996), to enhance resistance to phytopathogenic bacteria. The insertion, transcription, and translation of attE were confirmed in a transgenic line of 'M.7' apple rootstock, and fire blight resistance was enhanced (Norelli et al., 1994; Ko et al., 2000). Similarly, transgenic pear expressing attE showed a reduction of symptoms caused by E. amylovora in in vitro stem tissue (Reynoird et al., 1999).

T4L hydrolyzes $N$-acetylmuramyl-(1-4)- $\beta$-linkages in the peptidoglycan of bacteria (Düring, 1996). In addition, T4L has been reported to have microbicidal activity that is independent of its hydrolase activity (Düring et al., 1999). Bacteriophage T4 lysozyme

This work was supported by grants from the New York Apple Research and Development Program; the Cornell Center for Advanced Technology in Biotechnology, which is sponsored by the New York State Science and Technology Foundation and industrial partners; and USDA special grant 97-34367-3937.

${ }^{1}$ Department of Horticultural Sciences.

${ }^{2}$ Department of Plant Pathology.

${ }^{3}$ Current address: Biotechnology Foundation Laboratories at Thomas Jefferson University, 1020 Locust Street, Room 369 JAH, Philadelphia, PA 19107.

${ }^{4}$ Current address: USDA-Agricultural Research Service, Appalachian Fruit Research Station, 45 Wiltshire Rd., Kearneysville, WV 25430.
(T4L) inhibits the growth of E. amylovora in vitro (Mourgues et al., 1998b). Transgenic potato plants expressing the $T 4 L$ gene showed increased resistance to E. carotovora sp. atroseptica, causing potato soft rot (Düring et al., 1993).

Attacin increases permeability of the bacterial outer membrane and inhibits synthesis of some outer membrane proteins (Carlsson et al., 1991, 1998; Ourth et al., 1994). Carlsson et al. (1998) and Engström et al. (1984) hypothesized that in H. cecropia pupae attacin functions to increase the access of lysozyme to the peptidoglycan layer of bacteria. Attacin increased sensitivity of Escherichia coli to hen egg white lysozyme (HEWL) in vitro (Engström et al., 1984). In vitro synergy between cecropin and HEWL has been reported in the inhibition of E. amylovora (Mourgues et al., 1998b). The mode of action of HEWL is similar to that of T4L, but T4L shows greater in vitro inhibition of E. amylovora, although the reasons for the greater activity of T4L against E. amylovora are not known (Mourgues et al., 1998b).

The main goals of this research were to 1) genetically transform 'Galaxy' apple with both $a t t \mathrm{E}$ and $T 4 L$ genes, 2) study the expression of attE under the control of the potato proteinase inhibitor (Pin2) promoter, 3) determine the effect of the $T 4 L$ gene on fire blight resistance, and 4) investigate whether there is synergy between attacin and T4L with respect to resistance to fire blight in transgenic apple lines.

\section{Materials and Methods}

Plant transformation vectors. To construct p35SAMVT4 (Fig. 1A) the $T 4 L$ gene was restriction digested from pSR8-36 (Porsch et al., 1998) with $\mathrm{NcoI}$, and cloned into the NcoI site of pBI525 (Datla et al., 1993) to create pBI525T4. The HindIII and EcoRI fragment of pBI525T4 containing the cauliflower mosaic virus $35 \mathrm{~S}$ promoter with duplicated upstream $\mathrm{B}$ domain (35S) (Kay et al., 1987)/AMV/T4L/NOST was then cloned between the HindIII and EcoRI sites on pBI121 (replacing CaMV35S promoter/gus/ NOST) to produce p35SAMVT4. pLDB15 (Fig. 1B) (Ko et al., 2000; Norelli et al., 1994) contains the attE gene under the control of the Pin2 promoter (Pin2Att).

To construct pPin2Att35SAMVT4 (Fig. 1C) the HindIII frag- 
ment of pLDB15 containing Pin2 promoter (Pin2p)/attE/Pin2 terminator (Pin2t) (Destéfano-Beltrán et al., 1991) was cloned into the HindIII site in p35SAMVT4 to produce pPin2Att35SAMVT4.

DNA restriction, DNA ligation, and gel electrophoresis were performed using standard procedures (Sambrook et al., 1989). T4L of pSR8-36 and AMV/T4L of p35SAMVT4 were sequenced as described by Sanger et al. (1977) using a 373 DNA sequencer (Applied Biosystems, Foster City, Calif.) (Fig. 1B). The attE coding region was not sequenced in this study but had been sequenced previously (Ko et al., 1999). Each plasmid binary vector was transferred to Agrobacterium tumefaciens EHA105 using electroporation transformation (Dower et al., 1988). Insertion of $a t t \mathrm{E}$, the $\mathrm{AMV} / T 4 L$ gene fragment and the Pin2/attE/35S/AMV/ T4L gene fragment in each plasmid was confirmed using PCR and enzyme restriction analyses.

Plant materials. Tissue cultures of 'Galaxy' and 'Liberty' apple were obtained from stock cultures maintained in the Department of Plant Pathology, Cornell University, New York State Agricultural Experiment Station, Geneva. 'Galaxy' shoots were subcultured on an in vitro proliferation medium described by Norelli et al. (1988), but with altered plant growth regulator (PGR) concentrations of naphthaleneacetic acid (NAA) $\left(1 \mu \mathrm{g} \cdot \mathrm{mL}^{-1}\right)$, 6benzylaminopurine (BAP) $\left(1 \mu \mathrm{g} \cdot \mathrm{mL}^{-1}\right)$, and kinetin $\left(3 \mu \mathrm{g} \cdot \mathrm{mL}^{-1}\right)$. To produce leaves for transformation, shoots in proliferation medium were tangentially transplanted to leaf expansion medium, which differed in PGR [NAA $\left(1 \mu \mathrm{g} \cdot \mathrm{mL}^{-1}\right)$ and 6 - $(\gamma \gamma$-dimethylallylamino $)$ purine (2iP) $\left.\left(8.3 \mu \mathrm{g} \cdot \mathrm{mL}^{-1}\right)\right]$. Young leaves from leaf expansion medium were used for Agrobacterium-mediated transformation as described by Norelli et al. (1996).

CONFIRMATION OF TRANSFORMATION. Regenerants produced from leaf segments in regeneration culture with selection were transferred to proliferation medium containing paromomycin $\left(100 \mu \mathrm{g} \cdot \mathrm{mL}^{-}\right.$ $\left.{ }^{1}\right)$ and cefotaxime $\left(250 \mu \mathrm{g} \cdot \mathrm{mL}^{-1}\right)$. After 4 or 5 weeks on proliferation medium, leaves produced from one regenerated shoot were sampled for polymerase chain reaction (PCR) and a double-antibody sandwich enzyme-linked immunosorbent assay (ELISA) to detect neomycin phosphotransferase II (NPTII) to confirm transformation as described by Ko et al. (1998). To verify that the PCR bands obtained were not due to A. tumefaciens contamination, genomic DNA samples were amplified with primers for vir $\mathrm{G}$ as described by Ko et al. (1998). The same shoot was anchored tangentially into proliferation medium containing paromomycin $\left(100 \mu \mathrm{g} \cdot \mathrm{mL}^{-1}\right)$ for further propagation. Genomic DNA was extracted for PCR as described by Cheung et al. (1993). An attE primer set (Ko et al., 2000) and a $T 4 L$ primer set [T $L L$ forward (T4LF): 5'-GCT CTA GAA TGG GGA AGA ACGGCA GCCT-3' and T4L reverse (T4LR): 5'-CGG GAT CCT TAT AGA TTT TTA TAC GCG TCC CAA-3'] were used for PCR amplification of $a t t \mathrm{E}$ (453 bp) and T4L (590 bp) sequences, respectively (Fig. 1). The amplified T4L sequence contained the EcoRI site. The PCR program was 40 cycles of 1.5 $\min$ at $94^{\circ} \mathrm{C}, 2$ min at $55^{\circ} \mathrm{C}$, and 2 min at 72 ${ }^{\circ} \mathrm{C}$.

TOTAL RNA EXTRACTION AND RT-PCR. Total RNA was isolated from leaves of tissue cultured plants according to Verwoerd et al. (1989) with some modification (Ko et al., 2000). Northern blot analysis was conducted as described by Ko et al. (2000). To investigate the expression of the attE gene under the

B. pLDB15
Pin2 promoter, the leaves and stems of the tissue cultured plant were crushed with tissue forceps (Aesculap BD-591, Burlingame, Calif.). Leaves were harvested before wounding and 1,4 , and $24 \mathrm{~h}$ after wounding, frozen in liquid nitrogen, and stored at $-80^{\circ} \mathrm{C}$ until used for total RNA extraction.

Reverse transcription (RT) was conducted with $1 \mu \mathrm{g}$ of total RNA as described by Rosati et al. (1997). PCR reaction buffer solutions were prepared as described by Ko et al. (1998) and mixed with $2 \mu \mathrm{L}$ of cDNA sample. AttE, $T 4 L$, and EF 1 -a PCR reactions were conducted with attE primers (Ko et al., 2000), T4L primers (T4F and T4R), and EF1-a primers (Ko et al., 2000), respectively. PCR programs for $a t t \mathrm{E}, T 4 L$, and $E F 1$-a were 1) 40 cycles of $1.5 \mathrm{~min}$ at $94^{\circ} \mathrm{C}, 2 \mathrm{~min}$ at $55^{\circ} \mathrm{C}$ and $2 \mathrm{~min}$ at $72^{\circ} \mathrm{C}$; 2) $30 \mathrm{~s}$ at $94^{\circ} \mathrm{C}, 35$ cycles $\left(30 \mathrm{~s}\right.$ at $94{ }^{\circ} \mathrm{C}, 1 \mathrm{~min}$ at $65^{\circ} \mathrm{C}$, and $1 \mathrm{~min}$ at $72{ }^{\circ} \mathrm{C}$ ), and $1 \mathrm{~min}$ at 72 ${ }^{\circ} \mathrm{C}$; and 3) 5 min at $94{ }^{\circ} \mathrm{C}, 30$ cycles $\left(30 \mathrm{~s}\right.$ at $94{ }^{\circ} \mathrm{C}, 30 \mathrm{~s}$ at $58^{\circ} \mathrm{C}$ and $1 \mathrm{~min}$ at $72^{\circ} \mathrm{C}$ ), and $1 \mathrm{~min} 72^{\circ} \mathrm{C}$, respectively.

Evaluation of RESISTANCE TO E. amylovora. Transgenic lines and controls were rooted, acclimated in vitro (Bolaretal., 1998), and grown in a growth chamber at $25^{\circ} \mathrm{C}, 80 \% \mathrm{RH}$, conditions favorable for the development of fire blight. The two youngest actively growing leaves on 20 - to 30 -cm-tall potted plants with a single shoot were inoculated by cutting the leaves transversely with scissors dipped in an inoculum of $7.5 \times 10^{7}$ cfu of E. amylovora Ea273/mL (Ko et al., 2000; Norelli et al., 1994). The necrotic lesion length of the shoot was measured at $30 \mathrm{~d}$ after inoculation and divided by total shoot length to calculate percentage lesion length (\%LL), which was used to evaluate disease resistance. The replicate unit was a single shoot potted plant, and there were two to 18 replicates of each transgenic line for resistance evaluation. Evaluations were conducted twice, but not all lines were included in each test.

\begin{abstract}
Fig. 1. AttE and T4L genes in three different binary vectors for Agrobacteriummediated apple transformation. The T-DNA regions were transferred to 'Galaxy' using A. tumefaciens EHA105. 35S: cauliflower mosaic virus 35S promoter with duplicated upstream B domain (Kay et al., 1987); AMV: untranslated leader sequence of alfalfa mosaic virus RNA4 (Datla et al., 1993); NOST: terminator of nopaline synthase gene (Bevan, 1984); T4L: T4 lysozyme gene from T4 bacteriophage (Düring et al., 1993; Owen et al., 1983). This gene is fused to signal peptide of $\alpha$-amylase from barley (Rothstein et al., 1984). Pin2p and Pin2t: promoter and terminator of potato proteinase inhibitor II (Pin2) gene from potato, respectively (Destéfano-Beltrán, 1991); at $\mathrm{E}$ : cDNA of att $\mathrm{E}$ from $H$. cecropia (Destéfano-Beltrán, 1991; Kockum et al., 1984). All binary vectors contain the $n p t I I$ gene under the control of the NOS promoter for a selectable marker to confer resistance to the antibiotics kanamycin and paromomycin (Bevan, 1984). Arrow sets and a bar indicate the PCR primer sets for attE and T4L gene, and the sequenced region of $\mathrm{AMV} / T 4 L$, respectively.
\end{abstract}
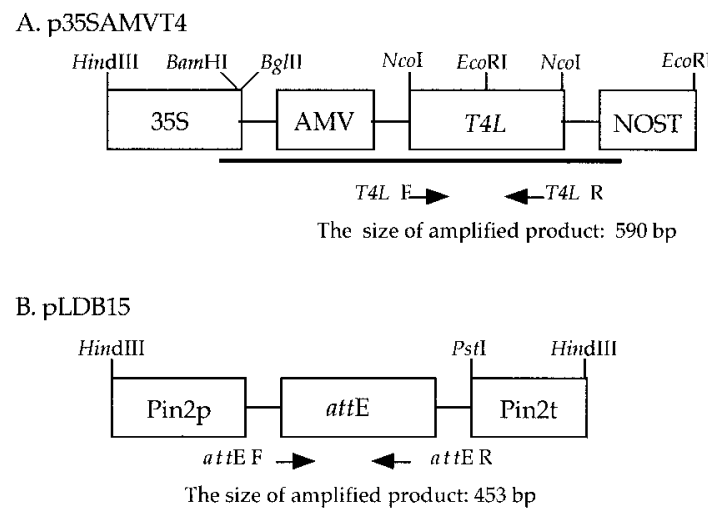

C. pPinAtt35SAMVT4

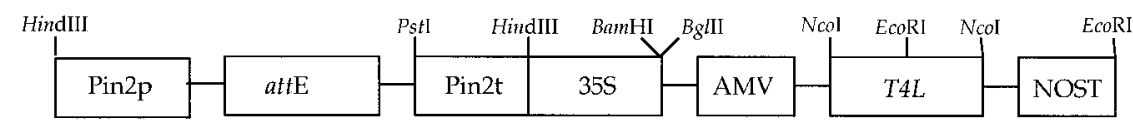


Since no significant interaction occurred between the tests, the data were combined using General Linear Model analysis (SAS Institute Inc., Cary, N.C.). 'Liberty' was included as a relatively resistant control cultivar. To test if there was synergy between attacin and T4L with respect to resistance to $E$. amylovora, a single degree of freedom contrast was tested with the null hypothesis $[\%$ LL of Pin2Att35SAMVT4 lines $=(\%$ LL of Pin 2 Att lines $+\% \mathrm{LL}$ of 35SAMVT4 lines)/2].

\section{Results and Discussion}

Construction of p35SAMVT4 AND pPin2Att35SAMVT4. Nucleotide sequence analysis indicated that both p35SAMVT4 and pSR8-36 contained the same T4L gene sequence. PCR and enzyme restriction analyses indicated that the AMV/T4L and Pin2/attE/35S/ AMV/T4L gene fragments were inserted into each p35SAMVT4 and pPin2Att35SAMVT4 plasmid (Fig. 1). The T4L sequence in newly constructed plasmids and pSR8-36 differed from the T4L sequence reported previously in that the nucleotides $\mathrm{T}(86)$ and $\mathrm{C}$ (103) of T4L gene (Owen et al., 1983) were mutated to A (86) and $\mathrm{G}$ (103), resulting in $\mathrm{Lys}^{29}$ and Gly ${ }^{35}$ being replaced by $\mathrm{Met}^{29}$ and $\mathrm{Arg}^{35}$, respectively. The potato transgenic lines transformed with pSR8-36 contain the same T4L mutations and are resistant to $E$. carotovora, indicating that the antibacterial activity of the mutant T4L is not altered in planta (de Vries et al., 1999; Düring et al., 1993; Düring, personal communication). The T4L gene in pSR8-36, p35SAMVT4 and pPin2Att35SAMVT4 is fused to $\alpha$-amylase signal peptide sequences from barley (Porsch et al., 1998). The attE gene sequences in pPin2Att35SAMVT4 had two silent mutations present in pLDB15 as described by Ko et al. (1999).

Transformation of 'Galaxy'. Transformation of 'Galaxy' apple was conducted three to six times for each construct. Most regenerants produced shoots after being transferred to proliferation medium containing paromomycin $\left(100 \mu \mathrm{g} \cdot \mathrm{mL}^{-1}\right)$. However, some regenerants turned chlorotic or necrotic, and died after transfer, indicating that they were escapes (Ko et al., 1998). All transformants that survived on the proliferation medium were able to amplify at $\mathrm{E}$ or full length $T 4 L$ and had significantly higher NPTII levels than nontransgenic 'Galaxy'. Transformation with pLDB15, p35SAMVT4, and pPin2Att35SAMVT4 produced nine, 22, and 20 transformants, for a transformation rate per inoculated leaf of 1.3, 7.4 , and $2.4 \%$, respectively.

AtTACIn EXPRESSION UNDER THE Pin2 PROMOTER. To investigate

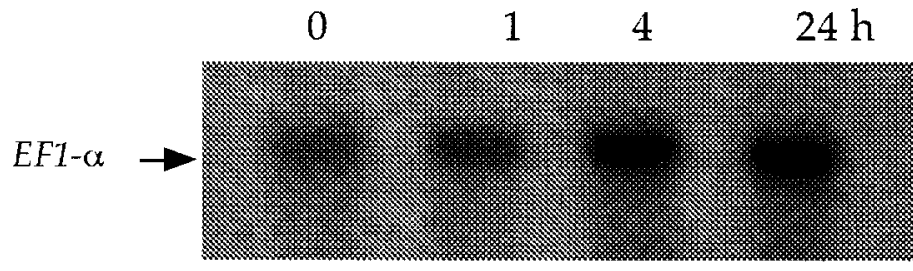

att $\mathrm{E}$

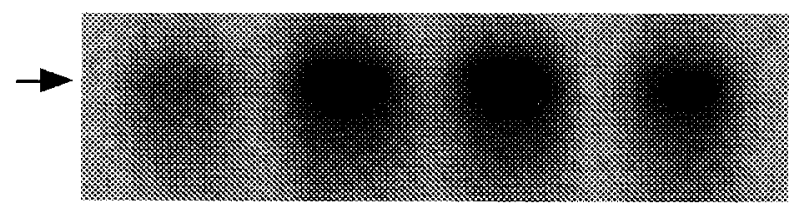

Fig. 2.Attacinexpression underthe control of $\operatorname{Pin} 2$ promoterintransgenic apple. Northern blot to investigate transcription level of $a t t \mathrm{E}$ gene at 0 (before wounding), 1, 4, and 24 $\mathrm{h}$ after mechanical wounding. Leaves and stems of tissue cultured plant were crushed with tissue forceps (Aesculap BD-591, Burlingame, Calif.). To verify equal amounts of RNA were loaded in all lanes, a northern blot membrane was stripped and rehybridized with a cDNA fragment probe from $E F 1$-a. whether the Pin 2 promoter is induced by mechanical wounding, western and northern blots were conducted in Pin2Att 'Galaxy'. With potted plants of Pin2Att 'Galaxy', attE gene expression was constitutive but increased after mechanical wounding (data not presented). The attacin amount between tissue cultured and potted plants was positively correlated (data not shown). Northern blot analysis indicated that the attE gene expression increased $1 \mathrm{~h}$ after wounding and decreased $24 \mathrm{~h}$ after wounding in a Pin2Att transgenic apple (Fig. 2). However, the attE mRNA gene was detected without wounding, supporting the results of western blot analyses where attacin protein was detected without wounding. These results indicate that the expression of $a t t E$ gene under the Pin 2 promoter is constitutive but mechanical wounding induced higher levels of expression. The Pin 2 promoter from potato is wound-inducible in potato and tobacco (Keil et al., 1989; Peña-Cortés et al., 1988; Sanchez-Serrano et al., 1987). Constitutive gene expression was also observed with the gus gene under the Pin2 promoter in transgenic tobacco (Thornburg et al., 1987). Keinonen-Mettälä et al. (1998) reported that the Pin 2 promoter resulted in greater constitutive gus gene expression than $u b i$, rolC, act 1 , and CaMV $35 \mathrm{~S}$ promoters in birch. In previous studies (Ko et al., 2000), the mean value of attacin expression under the control of the Pin2 promoter $\left(40 \mathrm{ng} \cdot \mathrm{mg}^{-1}\right)$ was similar to the $35 \mathrm{~S}$ promoter $\left(47 \mathrm{ng} \cdot \mathrm{mg}^{-1}\right)$ in transgenic apple. To avoid transcriptional gene silencing, which can be caused by homology in promoter regions (Matzke et al., 1994), Pin2 and $35 \mathrm{~S}$ promoters were used for $a t t \mathrm{E}$ and $T 4 L$ gene expression, respectively. A strong, constitutive promoter, such as the $35 \mathrm{~S}$ promoter could cause a greater incidence of post-transcriptional
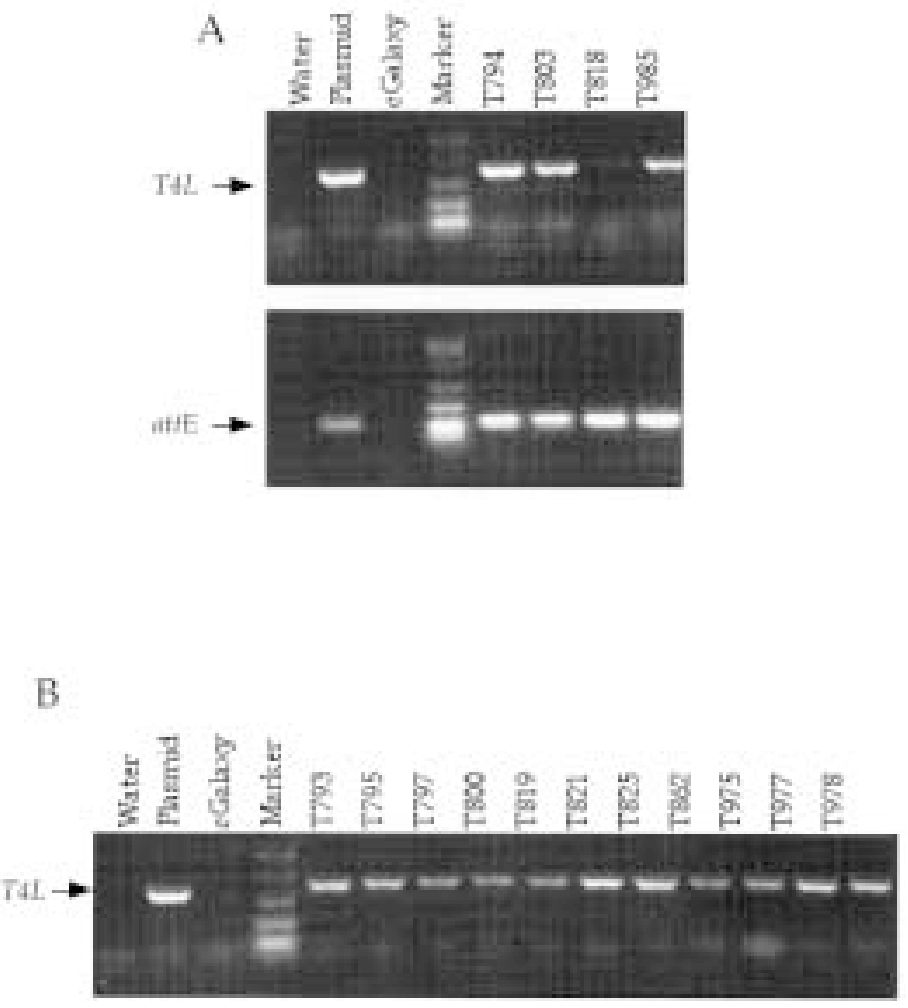

Fig. 3. RT-PCR to detect $T 4 L$ and $a t t E$ transcripts in (A) Pin2Att35SAMVT4 and (B) 35SAMVT4 transgenic lines of 'Galaxy' apple, that were evaluated for fire blight resistance. (A) Plasmid: pPin2Att35SAMVT4 binary vector; cGalaxy: reverse-transcribed cDNA sample from nontransgenic 'Galaxy'; Marker: PCR markers (Promega, Madison, Wis.). T4L amplified band size was 590 bp. AttE amplified band size was 453 bp. (B) Plasmid: p35SAMVT4 binary vector; cGalaxy: reverse-transcribed cDNA sample from nontransgenic 'Galaxy'; Marker: PCR markers (Promega). T4L amplified band size was 590 bp. 


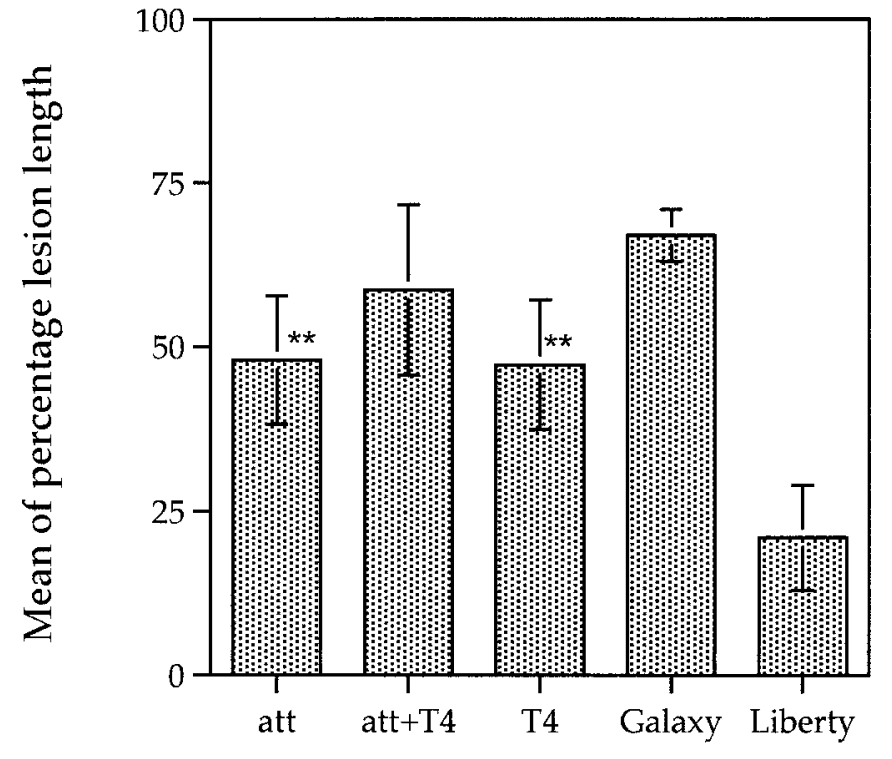

Line group

Fig. 4. The effect of T4L and attacin on disease resistance to E. amylovora. att, att+T4, and T4 indicate Pin2Att, Pin2Att35SAMVT4, and 35SAMVT4 transgenic line groups, respectively. 'Liberty' is a relatively resistant apple scion cultivar. The percentage lesion length was measured 30 days after E. amylovora Ea273 inoculation. The mean of percentage lesion length was obtained from two different disease evaluation events. Each group of Pin2Att, Pin2Att35SAMVT4, and 35SAMVT4 transgenic line includes seven, seven, and 14 transgenic lines, respectively. Each transgenic line had two to 18 replicate plants. Nontransgenic line group had 39 replicate plants. ${ }^{* *}$ Significantly less percentage lesion length of transgenic lines compared to nontransgenic line $(P=0.05)$.

gene silencing (PTGS) than a weaker promoter. In this respect, a nonconstitutive promoter might be better suited to avoid PTGS (Que et al., 1997). The moderately constitutive expression of attacin under the Pin 2 promoter suggests that the Pin 2 promoter could be a promising alternative promoter for high-level transgene expression in apple.

TransCription OF T4L AND attE GENES IN TRANSGENIC 'GALAXY' LINES. Eleven out of 22 transgenic lines for 35SAMVT4 and four out of 20 transgenic lines for Pin2Att35SAMVT4 were tested by RTPCR. The Pin2Att35SAMVT4 lines tested by RT-PCR showed amplification of both $T 4 L$ and attE (Fig. 3A), although line T818 showed weak amplification of T4L cDNA. All 11 of the 35SAMVT4 lines also showed amplification of T4L by RT-PCR but gave no attE amplification (Fig. 3B). Neither T4L nor attE amplification was detected by PCR of tested lines when the RNA sample was not treated with reverse transcriptase (data not presented), indicating that the T4L and attE amplification was not due to DNA contamination in the RNA samples. These results indicate the T4L gene was transcribed in transgenic 'Galaxy' lines.

RESISTANCE OF T4L TRANSGENIC LINES OF 'GALAXY' APPLE TO $E$. amylovora. Although RT-PCR indicated $T 4 L$ gene transcription in transgenic lines, western blots with a detection limit of $2 \mathrm{ng} \cdot \mathrm{mg}^{-1}$ (leaf fresh weight) failed to detect T4L protein (data not presented), suggesting that lysozyme concentration in these lines may be below the detection limit. However, five 35SAMVT4 lines [T793 (37.8 \%LL), T795 (39.9\%LL), T797 (41.0\%LL), and T975 (43.3\%LL)] had significant disease reduction compared to nontransgenic ' $\mathrm{Gal}$ axy' (67\%LL) and also, these transgenic lines were not significantly different from the relatively resistant 'Liberty' control (21.0\%LL), suggesting that even a low level of T4L might be sufficient to enhance resistance to E. amylovora in planta (Fig. 3B). A low level of T4L also enhanced resistance to E. carotovora in transgenic potato (Düring et al., 1993). Somaclonal variation also could play a role in the resistance to E. amylovora observed in some of these transgenic apple lines. After the lines have flowered, the effect of somaclonal variation on resistance will be evaluated in progeny of $T 4 L$ transgenic lines by determining the cosegregation of the transgene and resistance.

Pin2Att35SAMVT4 transgenic line group (58.6\%LL) tested were not significantly more resistant to $E$. amylovora than nontransgenic 'Galaxy' (67.0\%LL), although Pin2Att transgenic line group (47.9 \%LL) and 35SAMVT4L transgenic line group (47.2\%LL) showed significant increases in resistance (Fig. 4). A single degree of freedom contrast test showed that the null hypothesis [\%LL of Pin2Att35SAMVT4 lines $=(\%$ LL of Pin2Att lines $+\%$ LL of 35SAMVT4 lines)/2] was not rejected $(P=0.1217)$, indicating no evidence of a synergistic or additive effect of attacin and T4L in enhancing resistance.

These data suggested that although both attacin E and T4 lysozyme enhanced resistance to E. amylovora they were not synergistic in planta. The enhanced resistance of two Pin2Att lines [T606 (39.1\%LL) and T656 (33.0\%LL)] with the highest amounts of attacin among seven lines in this study is in agreement with previously published results showing a significant correlation between attacin content and disease resistance (Ko et al., 2000). Also, several 35SAMVT4 lines had significantly less infection than control lines as described above and expression of T4L in these lines appeared to be adequate to reduce infection. Therefore, the failure to detect additivity or synergy between attacin and T4L is unlikely to be due to lack of $T 4 L$ gene expression. Perhaps, the expression of both transgenes could have negative effects on the plant that might result in increased susceptibility to E. amylovora. High expression of attacin in pear was reported to cause reduced growth in vitro (Reynoird et al., 1999). However, in this study a reduction of plant growth was not observed in any Pin2Att35SAMVT4, Pin2Att, or 35SAMVT4 lines. Because biologically active, purified attacin E was not available, we were unable to evaluate the interaction of attacin $\mathrm{E}$ and T4L in vitro. To understand the interaction between attacin and T4L in planta, more information about the mode of the action of attacin and T4L is required. In addition, correlation between disease resistance and $T 4 L$ transcript level or T4L protein content in planta is required to understand the effect of T4L.

\section{Literature Cited}

Aldwinckle, H.S., J.L. Norelli, and M.T. Momol. 1998. Fire blight: The search for better control. New York Fruit Quart. 6:2-5.

Bevan, M. 1984. Binary Agrobacterium vectors for plant transformation. Nucl. Acids Res. 12:8711-8721.

Bolar, J.P., J.L. Norelli, H.S. Aldwinckle, and V. Hanke. 1998. An efficient method for rooting and acclimation of micropropagated apple cultivars. HortScience 33:1251-1252.

Borejsza-Wysocka, E.E., J.L. Norelli, K. Ko, and H.S. Aldwinckle. 1999. Transformation of authentic M.26 apple rootstock for enhanced resistance to fire blight. Acta Hort. 489:259-266.

Carlsson, A., P. Engström, E.T. Palva, and H. Bennich. 1991. Attacin, an antibacterial protein from Hyalophora cecropia, inhibits synthesis of outer membrane proteins in Escherichia coli by interfering with omp gene transcription. Infect. Immunol. 59:3040-3045.

Carlsson, A., T. Nyström, H. de Cock, and H. Bennich. 1998. Attacin-An insect immune protein-binds LPS and triggers the specific inhibition of bacterial outer-membrane protein synthesis. Microbiology 144:21792188.

Chen, F.-C. and A.R. Kuehnle. 1996. Obtaining transgenic Anthurium 
through Agrobacterium-mediated transformation of etiolated internodes. J. Amer. Soc. Hort. Sci. 121:47-51.

Cheung, W.Y., N. Hubert, and B.S. Landry. 1993. A simple and rapid DNA microextraction method for plant, animal, and insect suitable for RAPD and other PCR analyses. PCR Meth. Appl. 3:69-70.

Datla, R.S.S.,F. Bekkaoui, J.K. Hasmmerlindl, G. Pilate, D.I. Dunstan, and W.L. Crosby. 1993. Improved high-level constitutive foreign gene expression in plants using an AMV RNA4 untranslated leader sequence. Plant Sci. 94:139-149.

de Vries, J., K. Harms, I. Broer, G. Kriete, A. Mahn, K. Düring, and W. Wackernagel. 1999. The bacteriolytic activity in transgenic potatoes expressing a chimeric T4 lysozyme gene and the effect of T4 lysozyme on soil- and phytopathogenic bacteria. Syst. Appl. Microbiol. 22:280-286.

Destéfano-Beltrán, L. 1991. The introduction into tobacco plants of genes which encode some of the natural components of the humoral immune response of Hyalophora cecropia. PhD diss. La. State Univ., Baton Rouge.

Destéfano-Beltrán, L., P.G. Nagpala, S.M. Cetiner, T. Denny, and J.M. Jaynes. 1993. Using genes encoding novel peptides and proteins to enhance disease resistance in plants, p. 175-189. In: I. Chet (ed.). Biotechnology in plant disease control. Wiley-Liss, New York.

Dower, W.J., J.F. Miller, and C.W. Ragsdale. 1988. High efficiency transformation of E. coli by high voltage electroporation. Nucl. Acids Res. 16:6127-6146.

Düring, K., P. Porsch, M. Fladung, and H. Lörz. 1993. Transgenic potato plants resistant to the phytopathogenic bacterium Erwinia carotovora. Plant J. 3:587-598.

Düring K. 1996. Genetic engineering for resistance to bacteria in transgenic plants by introduction of foreign genes. Mol. Breeding 2:297-305.

Düring, K., P. Porsch, A. Mahn, O. Brinkmann, and W. Gieffers. 1999. The nonenzymatic microbicidal activity of lysozymes. FEBS Lett. 449:93100.

Engström, P., A. Carlsson, Å. Engström, Z.-J. Tao, and H. Bennich. 1984. The antibacterial effect of attacins from the silk moth Hyalophora cecropia is directed against the outer membrane of Escherichia coli. EMBO J. 3:3347-3351.

Kay, R., A. Chan, M. Daly, and J. Mcpherson. 1987. Duplication of CaMV $35 \mathrm{~S}$ promoter sequences creates a strong enhancer for plant genes. Science 236:1299-1302.

Keil, M., J.J. Sanchez-Serrano, and L. Willmitzer. 1989. Both woundinducible and tuber-specific expression are mediated by the promoter of a single member of the potato proteinase inhibitor II gene family. EMBO 8:1323-1330

Keinonen-Mettälä, K., A. Pappinen, and K. Von-Weissenberg. 1998. Comparisons of the efficiency of some promoters in silver birch (Betula pendula). Plant Cell Rpt. 17:356-361.

Ko, K., S.K. Brown, J.L. Norelli, and H.S. Aldwinckle. 1998. Alteration of $n p t \mathrm{II}$ and gus expression following micropropagation of transgenic M.7 apple rootstock lines. J. Amer. Soc. Hort. Sci. 123:11-18.

Ko, K., J.L. Norelli, S.K. Brown, and H.S. Aldwinckle. 1999. Anti-attacin polyclonal antibody from an in vitro derived antigen used for immunoblot to quantify attacin expressed in transgenic apple. Biotechnol. Technol. 13:849-857.

Ko, K., J.L. Norelli, J.-P. Reynoird, E.E. Boresjza-Wysocka, S.K. Brown, and H.S. Aldwinckle. 2000. Effect of untranslated leader sequence of AMV RNA 4 and signal peptide of pathogenesis-related protein $1 \mathrm{~b}$ on attacin gene expression and resistance to fire blight in transgenic apple. Biotechnol. Lett. 22:373-381.

Kockum, K., I. Faye, P.V. Hofsten, J.-Y. Lee, K.G. Xanthopoulos, and H.G. Boman. 1984. Insect immunity. Isolation and sequence of two cDNA clones corresponding to acidic and basic attacins. EMBO J. 3:2071-2075.

Matzke, A.J.M., F. Neuhuber, Y.-D. Park, P.F. Ambros, and M.A. Matzke. 1994. Homology-dependent gene silencing in transgenic plants: epistatic silencing loci contain multiple copies of methylated transgenes. Mol.
Gen. Genet. 244:219-229.

Montanelli, C. and G. Nascari. 1990. Resistance to bacterial disease: Preliminary results of a biotechnological approach in potato. Acta Hort. 280:537-540.

Mourgues, F., M.-N. Brisset, and E. Chevreau. 1998a. Strategies to improve plant resistance to bacterial diseases through genetic engineering. Trends in Biotechnol. 16:203-210.

Mourgues, F., M.-N. Brisset, and E. Chevreau. 1998b. Activity of different antibacterial peptides on Erwinia amylovora growth, and evaluation of the phytotoxicity and stability of cecropins. Plant Sci. 139:83-91.

Norelli, J.L., H.S. Aldwinckle, and S.V. Beer. 1988. Virulence of Erwinia amylovora strains to Malus sp. Novole plants grown in vitro and in the greenhouse. Phytopathology 78:1292-1297.

Norelli, J.L., H.S. Aldwinckle, L. Destéfano-Beltrán, and J.M. Jaynes. 1994. Transgenic 'Malling 26' apple expressing the attacin E gene has increased resistance to Erwinia amylovora. Euphytica 77:123-128.

Norelli, J.L., J. Mills, and H.S. Aldwinckle. 1996. Leaf wounding increases efficiency of Agrobacterium-mediated transformation of apple. HortScience 31:1026-1027.

Ourth, D.D., T.D. Lockey, and H.E. Renis. 1994. Induction of cecropin-like and attacin-like antibacterial but not antiviral activity in Heliothis virescens larvae. Biochem. Biophys. Res. Commun. 200:35-44.

Owen, J.E., D.W. Schultz, A. Taylor, and G.R. Smith. 1983. Nucleotide sequence of the lysozyme gene of bacteriophage T4. J. Mol. Biol. 165:229-248.

Porsch, P., A. Janke, and K. Düring. 1998. A plant transformation vector with a minimal T-DNA II. Irregular integration patterns of the T-DNA in the plant genome. Plant Mol. Biol. 37:581-585.

Peña-Cortés, H., J. Sanchez-Serrano, M. Rocha-Sosa, and L. Willmitzer. 1988. Systemic induction of proteinase inhibitor-II gene expression in potato plants by wounding. Planta 174: 84-89.

Que, Q., H.-Y., Wang, J.J. English, and R.A. Jorgensen. 1997. The frequency and degree of co-suppression by sense chalcone synthase transgenes are dependent on transgene promoter strength and are reduced by premature nonsense codons in the transgene coding sequence. Plant Cell 9:1357-1368.

Reynoird, J.P., F. Mourgues, J.L. Norelli, H.S. Aldwinckle, M.N. Brisset, and E. Chevreau. 1999. First evidence for differences in fire blight resistance among transgenic pear clones expressing attacin gene. Plant Sci. 149:23-31.

Rosati, C., A. Cadic, M. Duron, J.P. Renou, and P. Simoneau. 1997. Molecular cloning and expression analysis of dihydroflavonol 4-reductase gene in flower organs of Forsythia Xintermedia. Plant Mol. Biol. 35:303-311.

Rothstein, S.J., S.M. Lazarus, W.E. Smith, D.C. Baulcombe, and A.A. Gatenby. 1984. Secretion of a wheat alpha-amylase expressed in yeast. Nature 308:662-665.

Sambrook, J., E.F. Fritsch, and T. Maniatis. 1989. Molecular cloning: A laboratory manual. Cold Spring Harbor Laboratory Press, Cold Spring Harbor, N.Y.

Sanchez-Serrano, J.J., M. Keil, A. O'Connor, J. Schell, and L. Willmitzer. 1987. Wound-induced expression of a potato proteinase inhibitor II gene in transgenic tobacco plants. EMBO J. 6:303-306.

Sanger, F., S. Nicklen, and A.R. Coulson. 1977. DNA sequencing with chain-terminating inhibitors. Proc. Natl. Acad. Sci. USA 74:5463-5467.

Sobiczewski, P., T. Deckers, and J. Pulawska. 1997. Fire blight (Erwinia amylovora) Some aspects of epidemiology and control (review of recent literature). Res. Inst. Pomol. Floricult., Skierniewice, Poland.

Thornburg, R.T., G. An, T.E. Cleveland, R. Johnson, and C.A. Ryan. 1987. Wound-inducible expression of a potato inhibitor II-chloramphenicol acetyltransferase gene fusion in transgenic tobacco plants. Proc. Natl. Acad. Sci. USA 84:744-748.

Verwoerd, T.C., B.M.M. Dekker, and A. Hoekema. 1989. A small-scale procedure for the rapid isolation of plant RNAs. Nucl. Acids Res. $17: 2362$. 